\title{
Racism and Disability in Joe Penhall's Blue/Orange
}

\author{
By: Rufaidah Gamal Thabet
}

M. A. Researcher 


\section{Abstract}

It might well be argued that disability and racism are socially-constructed concepts that operate on divergent and versatile levels. Blacks and disabled people alike face challenges, barriers, discrimination, and marginalization. The present study attempts to explore the intersectionality of disability and racism in the British playwright Joe Penhall's (1967- ) Blue/orange (2000). The paper draws upon Literary Disability Theory and Critical Race Theory. Literary Disability Theory focuses on how literary representations of disability negatively influence the way disabled people are perceived and treated in society. Critical Race Theory scrutinizes and interrogates race, racism, power relations, and privilege. Blue/Orange draws insightful correlations between disability and racism and unmasks the role of society and institution in discriminating and marginalizing black people with disabilities. Penhall does not present Christopher, the disabled character in the play, in a stereotypical or a metaphorical way; rather he portrays his feelings, hopes, and fears in a way that represents the character as it is and not as a symbol. The paper investigates the challenges that black people with psychological disability face in society, and how institutional racism operates in psychiatric hospitalization, and how psychiatry and medical diagnosis are pervaded by racial ideas about black disabled people. Through the exploration of the intersectionality of disability and racism, this study attempts to present the lived experiences of black disabled people in society.

Keywords: disability, racism, Critical Race Theory, Literary Disability Theory. 


\section{العنصرية والإعاقة في مسرحية جو بينهول (أزرق/ برتقالي)}

مستخلص

تعتبر الإعاقة والعنصرية من المفاهيم المبنية على أساس اجتماعي, واللذان يعملان في مستويات

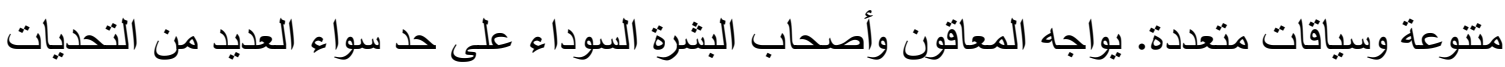
المتمنكة في العراقيل والتمبيز والتهميش. تتتاول هذه الدراسة العلاقة المتداخلة بين الإعاقة والعنصرية

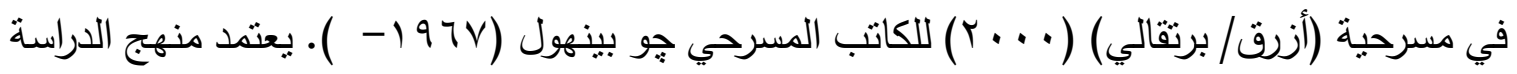
على النظرية الأدبية للإعاقة والنظرية النقدية للعِرق. تسلط النظرية الأدبية للإعاقة الضوء على صورة الإعاقة والمعاقين في الأدب, وكيف أنها تؤئز سلباً على الطريقة التي يرى بها النهابهـ المجتمع المعاقين ويتعامل معهم. بينما تبحث النظرية النقدية للعِرق في ماهية مفاهيم العِرق والعنصرية وعلاقات القوى إدى والامتياز • تصور مسرحية (أزرق/ برتقالي) العلاقة المتبادلة بين الإعاقة والعنصرية, وتميط اللثام عن فئه الدور الذي يلعبه المجتمع والمؤسسات في تمييز وتهميش المعاقين من أصحاب البشرة السوداء. يبتعد جو بينهول في تصويره لبطل المسرحية المعاق كريستوفر عن النمطية والرمزية, مصوراً لنا مشاعره وآماله ومخاوفه بطريقة تمنل الثخصية كما هي وليست مجرد رمزاً. تنتاول الدراسة التحديات التي يواجهها أصحاب البشرة السوداء ممن يعانون من الإعاقات النفسية, كما تتطرق إلى عنصرية الطب النفسي والتشخيص الطبي ضدهم. عبر دراسة العلاقة المتداخلة بين الإعاقة والعنصرية, تسعى هذه الإهي الورقة البحثية إلى عرض صورة حقيقية للتجارب الحياتية التي يعيشها المعاقين من أصحاب البشرة

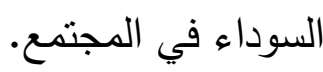
الكلمات المفتاحية: الإعاقة, العنصرية, النظرية النقدية للعِرق, النظرية الأدبية للإعاقة. 
It might be well argued that disability and racism are sociallyconstructed concepts that operate on divergent and versatile levels. Blacks and disabled people alike face challenges, barriers, discrimination, and marginalization. The present study attempts to explore the intersectionality of disability and racism in the British playwright Joe Penhall's (1967- ) Blue/orange (2000). The paper draws upon Literary Disability Theory and Critical Race Theory. Penhall does not present Christopher, the disabled character in the play, in a stereotypical or a metaphorical way; rather he portrays his feelings, hopes, and fears in a way that represents the character as it is and not as a symbol. The paper investigates the challenges that black people with psychological disability face in society, and how institutional racism operates in psychiatric hospitalization, and how psychiatry and medical diagnosis are pervaded by racial ideas about black disabled people.

Despite their considerable number in the world, people with disabilities still represent a minority in society. They regularly encounter discrimination and stigma that prevent them from full participation in society. Therefore, disability studies emerge to "name [these] states of social oppression unique to people with disabilities, while asserting at the same time the positive values that they may contribute to society" (Siebers 4).There are two fundamental grounds for disability studies: the first is the distinction between disability and impairment; whereas the second is the treatment of disability as a social construct.

In addition, Literary Disability Theory focuses on how literary representations of disability negatively influence the way disabled people are perceived and treated in society. In Disabled Literature Miles Beauchamp maintains that the subject of disability is "either avoided or presented in a stereotypical and often negative manner. Individuals with disabilities are portrayed as helpless, or super-abled; pure and good, or evil monsters" (23). Literary Disability Theory attempts to eradicate these stereotypes as they do not convey the lived experience of disabled people. 
Blue/Orange focuses on young black Christopher who suffers from "psychological disability", a term that is used "when mental illness significantly interferes with the performance of major life activities, such as learning, working, and communicating" ("What is Psychiatric Disability"). Borderline personality disorder and schizophrenia are considered psychological disabilities. According to the Diagnostic and Statistical Manual of Mental Disorders (DSM-5), Borderline personality disorder is "a pervasive pattern of instability of interpersonal relationships, self-image, and affects, and marked impulsivity, beginning by early adulthood and present in a variety of contexts" (663). Schizophrenia is a disorder "defined by abnormalities in one or more of the following five domains: delusions, hallucinations, disorganized thinking (speech), grossly disorganized or abnormal motor behavior (including catatonia), and negative symptoms" (DSM-5 87). The British Psychological Society maintains that people who suffer from schizophrenia may experience stigma because of mental health regulations that require mandatory treatment in the community which may, in turn, intensifies their feelings of exclusion (17).

The ideology of racism is based upon the assumption of the superiority of one particular race over another. The term "race" denotes the belief that humans can be grouped according to visible features such as skin color, facial features, culture traits, etc.. Wilton Krogman defines race as "a subgroup of people possessing a definite combination of physical characteristics, of genetic origin, the combination of which to varying degrees distinguishes the sub-group from other sub-groups of mankind" (49). The idea that race indicates biological truths about people has been used to justify slavery. Audrey Smedley and Brian Smedley hold that the ideology of race has begun in the late 17th century "in conjunction with the legal establishment of slavery for Africans", leading to the creation of "three major groups ... European Whites, Native Americans, and Negroes" (20). 
Racism can be defined as the belief, attitude, or policy which subordinates individuals, groups, or societies based on their race. In "Race, Racism, and Discrimination", Bobo and Fox define racism as:

A set of institutional conditions of group inequality and an ideology of racial domination, in which latter is characterized by a set of beliefs holding that the subordinate radical group is biologically or culturally inferior to the dominant racial groups. These beliefs, in turn, are developed to prescribe and legitimize society's discriminatory treatment of the subordinate group and to justify their lower status. (319)

Racism does not only involve negative attitudes and beliefs but also the social power that enables a dominant group to oppress other races or provide special privileges to one's race at the expense of others. In his book Social Theory, Psychoanalysis, and Racism, Simon Clarke identifies two forms of racism: individual and institutional racism. Individual racism denotes prejudice against people based on biological considerations. According to Clarke; "the fact that people hold prejudices is enough to make others feel excluded" (25-26). Institutional racism includes intentional or unintentional manipulation or toleration of institutional policies that restrict the opportunities of targeted groups. Clark regards institutional concept as a complex one; "on one level it may be defined as 'the discriminatory impact of administrative procedures'. On the other, it is a complex interaction between a silent racist discourse which has become embodied within an institution which is reinforced and interacts with individuals within that institution" (26).

Critical Race Theory has emerged as a reaction against the deficiency in critical legal studies. During the 1970s, legal scholars have assumed that "law [is] established by societal power relationships" and that court decisions reflect a "bias with a mask of blind legitimacy" (Martinez 19). Consequently, a new legal movement called critical legal studies has appeared to challenge and address the unjust legal status quo. Nevertheless, in the 1980s a group of 
legal scholars has criticized critical legal studies because of its failure "to acknowledge how race is a central component to the very systems of law being challenged" (Martinez 17). Therefore, a new movement known as Critical Race Theory has come out to scrutinize race, racism, power, and privilege in diverse contexts and discourses. According to Glenn Bracey:

Critical Race Theory is a broad theoretical framework created by synthesizing the main themes of scholars who have challenged dominant contemporary understandings of race and the law, as well as other aspects of social structural inequalities. It began a racial intervention in critical legal studies before growing into a distinct theoretical perspective of its own. (553)

The field is based on the work of Derrick Bell, Richard Delgado, Alan Freeman, Kimberlé Crenshaw, Charles Lawrence, Mari Matsuda, and Patricia Williams. Those scholars interrogate race, racism, and power relations as well as critique the notions of objectivity, meritocracy, and color blindness. Nicholas Hartlep proposes five tenets of Critical Race Theory:

There are five major components of tenets of critical race theory: (1) the notion that racism is ordinary and not aberrational; (2) the idea of an interest convergence; (3) the social construction of race; (4) the idea of storytelling and counter-storytelling; and (5) the notion that whites have actually been recipients of civil rights legislation. (155-156)

Critical Race Theory regards racism as so deeply entrenched in the social order that it is often taken for granted and viewed as natural. According to Derrick Bell, white people seek racial justice when there is something in it for them; "the interest of blacks in achieving racial equality will be accommodated only when it converges with the interests of whites" (22). Whites attempt to achieve racial equality and justice whenever this suits their interests. 
Moreover, Critical Race Theory places great importance on the voices and experiences of people of color. Their accounts sometimes take the form of story-telling or counter-narrative and may be semi-autobiographical or allegorical. As a tool, "Stories by people of color can counter the stories of the oppressor" (Tate 220). Moreover, scholars of Critical Race Theory highlight that white supremacy is ingrained in the political, economic, and cultural system "in which whites overwhelmingly control power and material resources, conscious and unconscious ideas of white superiority and entitlement are widespread, and relations of white dominance and nonwhite subordination are daily reenacted across a broad array of institutions and social settings (Ansley 1024)".

Another important tenet in Critical Race Theory which is originally advanced by Kimberlé Crenshaw is the concept of intersectionality, which is used to "describe both how people experience multiple social systems at once and a scholarly approach to analyzing and researching this multiplicity of identities, oppressions, and privileges" (Schalk 7). Intersectionality describes the intersection of race, gender, class, and other individual characteristics with one another. On the other hand, Critical Race Theory criticizes essentialism, which is the belief that all people perceived to be in a single group that think, act, and believe the same thing in the same way. Critical Race Theory undertakes an anti-essentialist stance in order to recognize colored people's experience. Bill Hooks maintains that "employing a critique of essentialism allows Africans to affirm multiple black identities, varied black experience. It also challenges colonial imperialist paradigms of black identity which represent blackness onedimensionally in ways that reinforce and sustain white supremacy" (59). Therefore, adopting an anti-essentialism approach challenges the idea that there is one black experience and takes into account their specificity and diversity. 
Disability and racism share points of similarities. In "Unspeakable Offenses", Erevelles and Minear illustrate three points of contact. Firstly, disability and racism are social constructs that derive meaning and significance from the social, political, cultural, economic, and historical structures. Secondly, race and disability are "theorized as relational concepts" (358). Critical Race Theory scholars argue that "races are constructed relationally against one another, rather than in isolation" (Lopez 28). For example, the privileges that the whites enjoy relate to the subordination of colored people. In a similar way, disability studies scholar Lennard Davis indicates that "our construction of the normal world is based on radical repression of disability" (22). Thirdly, both categories depend upon personal narratives and accounts to reveal the experience of oppressed and discriminated people.

Being black and disabled makes disabled blacks suffer from double oppression. The term was coined by Nasa Begum, Mildrette Hill, and Andy Stevens in 1994 (qtd. in Fawcett 158). Double oppression enables individuals to see how their identities intersect and overlap in structuring their oppression and discrimination on individual, societal, and institutional levels. Black disabled people do not only experience discrimination and marginalization in society, but also within the black and disabled communities.

The association of disability with blacks has historical roots. Douglas Baynton suggests that; "Non-white races were routinely connected to people with disabilities, both of whom were depicted as evolutionary laggards or throwbacks" (36). Blacks have been said to flourish in their normal condition of slavery, while the free Negro inevitably fell into illness, disability, and eventually extinction. In his 1873 textbook Physical Geography, Arnold Guyot compares the beauty and regularity of features of the white race with the deviated forms of black people (115-118). This attachment of disability to Black people has increased their oppression and discrimination. Erevelles 
and Minear illustrate that "historically, associations of race with disability have also been used to justify the brutality of slavery, colonialism, neocolonialism, and the continued exploitation of people of color" (11).

Joe Scott Penhall (1967- ) is an English playwright and screenwriter. He was born in Surrey, London. He joined the Royal Court Young People's Theatre, where he was taught by distinguished playwrights Caryl Churchill, April De Angelis, and Hanif Kureishi. Amongst his best plays are: Some Voices (1994), Pale Horse (1995), Love and Understanding (1997), The Bullet (1998), Blue/Orange (2000), Dumb Show (2004), Landscape With Weapon (2007), Haunted Child (2011), Birthday (2012), Sunny Afternoon (2014), and Mood Music (2018) (“Joe Penhall”).

In Blue/Orange, Penhall does not only scrutinize the notions of disability, normalcy, and psychosis, but he also complicates them with racism, discrimination, and oppression. The play tackles issues of racism, disability, and power struggle in British society. Aleks Sierz notes that "Blue/Orange picked up on widespread anxieties about psychotic individuals roaming the streets of Britain's cities, and a fear of violent black men" (104).

The play consists of three acts. The setting is in a modern psychiatric hospital of the National Health Service (NHS) in London. Christopher is a 24- year old black person who suffers from psychological disability. Doctor Bruce, in his late 20s, is a white psychiatrist in his first year of training. Robert, in his 50s, is a white senior consultant and Bruce's supervisor. The play centers on Christopher, who has been arrested by the police for his misbehavior in public and taken to the psychiatric hospital. Dr. Robert diagnoses him with a borderline personality disorder. After a month of confinement, Christopher is about to leave the hospital. However, Bruce thinks that he needs further hospital treatment and diagnoses him with schizophrenia after Christopher shows symptoms of hallucinations and delusions. He believes that oranges are blue and that Idi Amin, an African 
dictator, is his father. Nevertheless, Dr. Robert insists on his own diagnosis (borderline personality disorder), and is convinced that Christopher should be released back into the community. His convention is based on two reasons. Firstly, he is motivated by shortage of hospital beds. Secondly, he believes that Bruce's diagnosis rests on ethnocentric bias. He assumes that white doctors tend to deem blacks as schizophrenic patients. The disagreement between the two doctors accentuates and, eventually, Robert persuades Christopher to lodge a complaint against Bruce charging him of racism.

The intersectionality of racism with disability is the main theme in Blue/Orange. The oppression exercised by white doctors, Dr. Bruce and Dr. Robert, against Christopher is evident from the beginning. At the beginning of the play Christopher expresses his happiness for his departure:

CHRISTOPHER. It's my nervous. I'm getting out tomorrow. You can't tell me what to do when I get out- when I'm out there- which is in (checks his watch) exactly twenty-four hours. I'm not under your... it's none of your business then man. I'm twenty- four hours away from freedom. Out of this hole. D'you know what I mean? (1.13)

Christopher's happiness does not stem from being cured or rehabilitated; rather it is because he will not be under the white doctors' control and supervision. He will get back "there" where doctors cannot tell him what to do and not do. He does not only want to escape from the hospital's racial environment, but also from the prejudiced society. Christopher desires a place where he can get what he has been deprived of; a place where he can find his self-esteem, respect, and security:

CHRISTOPHER. I'm going far away where I can get some peace and quiet, ... no neighbours squatting on my head, under the floor, through the walls, rowing all day and night. Nothing. No people at all, man, and 
nobody looking at me funny like they never seen a Brother before except on fucking Sesame Street! (1.16)

Christopher needs a place where he cannot be ridiculed or treated as other. His words recapitulate the discrimination suffered by colored people with psychological disabilities. According to Katerina Ziaka; "Penhall attributes his protagonist's impaired mental state to his inability to adjust to a ghetto and to the dehumanizing impact of social structures such as institutional establishments and scientific discourse" (138). It can be assumed that the discrimination and oppression in Christopher's social environment have led to his psychological disability.

However, Christopher is stopped a lot by the police in White City, where he lives. This makes him suspicious of the authorities and feels paranoid. He also suffers from hallucinations and delusions. He sees oranges as blue. According to Shih Chun-Yi "blue orange, becomes an analogy of Christopher, a black man in white society. "Blue orange" further is indicative of Christopher's uncertainty of selfhood. He is an African from London, but when people see him, they only see his skin color, that is, his external appearance, rather than his internal substance" (82). Christopher's skin color and apparent unstable behavior attract people's looks. He tells Robert: "People stare at me. Like they know ... like they know about me. Like they know something about me that I don't know" (2.54). The stare here operates on two levels; disability and racism. According to disability scholar Rosemarie Garland-Thomson; "The kind of staring that "fixes" a person in gender, race, disability, class, or sexuality systems is an attempt to control the other" (43). The stare acts as an oppressor which puts Christopher under the 'normal', 'standard', and 'white' microscope as well as excludes and alienates him because he is the 'other'. Moreover, Garland-Thomson points out that "Staring can also be a social act that stigmatizes by designating people whose bodies or behaviors cannot be readily absorbed into the visual status quo" (44). The stare and stigma traumatize Christopher and contribute 
to his mental condition. They impel him to question his existence and identity as if he is not a 'normal' person:

CHRISTOPER. I am being harassed. I' $m$ in fear of my life. I live in fear. They Know Who I Am.

ROBERT. Who does?

CHRISTOPER .The men. Where I live. The noises. The ... the police. It all makes sense.

ROBERT. They're . . look . . it's . . they're just ordinary men. Workmen ... policemen.

CHRISTOPER. Other men too. Another man. He throws bananas at me. ROBERT. Bananas ... ?

CHRISTOPER. When I'm at work. Even at work-d'you know what I mean! Big bloke with a little pointy head. Long thin arms trailing along the ground. A real knuckle-dragger. Very white skin. Hideous-looking bastard. He's the ring-leader. I see him at night. He bangs on my door. Says he's coming to get me. He says he'll do me and nobody would even notice and I believe him. There's a whole family of them. A tribe. I don't like them at all. They're a race apart. Zombies! The undead. Monsters! (2.60)

Christopher describes his horrific experience of discrimination and insecurity. "Zombies! The undead. Monsters!" and "Very white skin" manifest his daily life experience of racism in the white British society. No wonder the playwright chooses "White City" as a place Christopher lives in.

Furthermore, Christopher believes that he is a son of Idi Amin, the former Ugandan president, another delusion he suffers. He even shows Robert a newspaper article about Amin, which he keeps in his wallet. Here, 
Christopher claims an impossible identity. As psychiatrist Suman Fernando remarks; "Debasing of self-esteem is something that racism, especially when it is subtle, induces. A common strategy to deal with this is assumed heightened self-importance - an instinctive feeling that one is someone special or comes from a superior culture or family" (184). Christopher tries to establish himself as an important individual, thus claims a strong identity. But why does Christopher specifically choose this dictator? It can be argued that by ascribing himself to Idi Amin, who has had tremendous authority and influence, Christopher feels secure and strong. By claiming that he is the son of a powerful African dictator, Christopher takes shelter in the delusion of domination to escape the dehumanizing treatment he daily suffers from.

It can be argued that Blue/Orange criticizes the doctors who are interested in authority and power more than the recovery and recuperation of the patients. By focusing on the clinical debate and power struggle between the two psychiatrists, Robert and Bruce, who argue the validity of their theories of treatment, Penhall raises important critiques about psychiatric practices that include racist ideology and power imbalances between patients and doctors:

BRUCE. Christopher is a schizophrenic.

Pause.

Did you hear me?

ROBERT. No, he's BPD. (1.22)

ROBERT. How does BPD with paranoia sound? Stick to the ICD 10 Classification. 
BRUCE. You love the ICD 10 don't you? All the different euphemisms for 'He's Nut' without actually having to admit he's nuts. It's like your Linus blanket. (1.23)

Penhall is a critical observer of the psychiatry profession, with a nuanced grasp of medical hierarchy and the process of diagnosis. It is obvious that Robert and Bruce care little about Christopher. Their allegiance is to their careers and their argument is more about their self-interestedness (interest convergence according to principles of Critical Race Theory) rather than a true concern. Moreover, institutional racism is expressed mainly through the diagnosis of Robert, who presumes that Christopher's mental illness is due to his ethnic roots because blacks suffer from psychosis:

BRUCE. What are you talking about? You can't use him for research.

ROBERT. Why not? Why ever not? Think about it. There is more mental illness amongst the Afro-Caribbean population in London than any other ethnic grouping.

What if there is a cure? A 'cure' for 'black psychosis'. (1.43-44)

Robert assumes that Christopher's mental illness is a means of dealing with the concerns and worries that he faces in society. Consequently, from Robert's point of view, anger and delusions are the only outlet for Christopher. Robert's assumptions are based on Ronald David Laing's philosophy of anti-psychiatry. Robert admires his treatment methods and quotes his sayings. Laing is a Scottish psychiatrist who has proposed an alternative treatment of mental illness, away from medical drugs and hospitalization that puts much emphasis on self-expression and communication of the patients (Beveridge 452). Robert believes that Christopher's mental disorder is caused by his environment. Therefore, he decides to send Christopher back to society. He assures Bruce that discharging Christopher is the right thing according to psychiatric textbooks: 
ROBERT. He's going back to his people.

BRUCE. His 'people' ? He doesn't have any people. He doesn't have a life.

ROBERT. That's a matter of conjecture.

BRUCE. It's true. He's on the White City Estate. It's a predominantly Jamaican community, he didn't grow up there, he doesn't know anybody and he hates it.

ROBERT. What about family? He must have a mother.

BRUCE. He doesn't seem to be in contact with her anymore. (1.21)

Robert overlooks the conditions of Christopher, who has no family or friends in White City. Furthermore, he fails to notice that the community adds to his mental state. Instead of providing a suitable therapy, Robert is anxious to send Christopher back to society in order to prove his theory about "black psychosis".

On the other hand, Bruce's persistence on his point of view in the face of different arguments makes him seem unbalanced and even obsessed with controlling Christopher. Although he cares about Christopher, he shows over-confidence in his judgment that indicates power and white supremacy. In doing so, he assumes the colonizer's attitude. He dictates what Christopher should and should not do:

BRUCE. Would you like a cup of water?

CHRISTOPHER. Coke.

BRUCE. No you can't have -

CHRISTOPHER. Ice cold Coke. The Real Thing.

BRUCE. No you know you can't have Coke - 
CHRISTOPHER. Yeah I can because -

BRUCE. What did I tell you about Coke?

CHRISTOPHER. I'm going home tomorrow.

BRUCE. What's wrong with drinking Coke?

CHRISTOPHER. But I'm going home. (1.2)

Bruce is obsessed with instructing Christopher. He even attempts to control his simple requests (such as coke and cigarettes). When he knows that Christopher has lodged a complaint against him, thus ruining his career, he loses his temper and declares his racial views:

BRUCE. They're black! All your neighbours are. It's a Black Neighbourhood. You you you moron. You stupid fool. Are you retarded? Jesus! This is the thanks I get for rotting in this stinking hell hole, pushing shit up hill, watching what I say, tiptoeing around, treading on eggshells, kissing arse while you sit around laughing and squawking and barking like a freak. You didn't know if you were arthur or martha when you came in here and this is the thanks I get. Now You're upset. Now I've upset you. Good. Good. See how much you like it. (3.104)

Bruce's usage of degrading names such as moron, fool, retarded, and freak is an evidence of his discrimination as a psychiatrist. Though psychiatrists are required to be impartial in their treatment, here Bruce is quite the opposite. He considers Christopher as ungrateful freak nigger. In Theatre as Public Discourse: A Dialogic Project (2016), Antony Weir remarks that "Bruce's willingness to attribute madness to Christopher is testament to his own entrenched, cultural assumptions as a white doctor treating a black patient" (49). The medical diagnosis of Bruce is ethnocentric and subject to racial assumptions. Thus, his bias entails discriminatory methods, treatment, and diagnosis. 
The language in Blue/Orange plays a dynamic role as an instrument of power too. Rachel Clements notes that "[Penhall] uses a range of linguistic registers- including medical jargons, cultural reference, colloquialisms, and the language of anti-psychiatry- in order to demonstrate the ways in which power operates in institutions" (XLIII). Robert and Bruce use language of power which manifests institutional corruption:

ROBERT. Now. Do you want me to recommend your consultancy at this hospital or don't you?

BRUCE. Of course.

ROBERT. Then act like a professional. Act like a representative of the Royal College of Psychiatrists.

BRUCE. But I'm not a -

ROBERT. Do you want to be? Mm? Now. Pull yourself together. Try not to be so wet behind the ears. Otherwise I'm taking you off this case.

BRUCE. You can't take me off this case.

ROBERT. I'll assign a CPN and discharge him myself.

BRUCE. If you do I'll appeal to the Authority.

ROBERT. I am the Authority. (Just between you and me.) (1.47)

Robert misuses his power and authority and reveals malfeasance. Furthermore, he later attempts to manipulate Christopher's mind by alleging that Bruce is an ethnocentric person and that he wants to punish Christopher because he is black. Eventually the latter lodges a complaint against Bruce:

CHRISTOPHER. What did he say? 
ROBERT. Well ... well ... since you asked ... I think he has a very real fear that ... our response to you is weighted by our response to your colour. I personally feel that should be the case; it should be a factor in your treatment and that we shouldn't overlook such a thing. Otherwise what happens, in institutions such as this, there develops what's termed "Ethnocentricity"; which ordinarily is fairly harmless but in certain instances is not far off ... well ... it is the progenitor of 'Cultural Oppression', which in turn leads to what we call 'Institutional Racism'.

CHRISTOPHER. Racism?

ROBERT. Yes. And the danger is that in a sense you maybe end up, in a sense, being 'punished' for the colour of your skin. (Beat.) For your ethnicity and your attendant cultural beliefs. (Beat.) You are sectioned and locked up when you shouldn't be. (Beat.) Because you're 'black'.

Silence

CHRISTOPHER. I'm being punished?

ROBERT. Maybe that's too strong a term but but but-

CHRISTOPHER. Because I'm black?

ROBERT. Well you see, the system is flawed. People of ethnic minority are not well catered for, it's a well-known fact. I've just expressed it clumsily-

CHRISTOPHER. He said that? I'm locked up because I'm black? (2.7273)

Robert attempts to manipulate Christopher's mind in order to convince him to submit a complaint against Bruce. The white doctor exploits Christopher's fragile state of mind to gain supremacy over his black disabled patient and white fellow. His carefully chosen words, such as "Cultural Oppression", 
"Ethnocentricity", "Institutional Racism", pose a threat to Christopher and change his opinion about Bruce. In turn, Christopher manipulates language and makes use of it to resist discriminatory treatment:

[Bruce] reads

'He snatched away a cup of coffee given to the patient by the consultant ... He used the pejorative epithet "nigger".'

Silence.

I did not, um, my God, I didn't use the epithet ... nnn ... .

He stares.

I did not call you a . . um, um, um, a . . I I didn't say that.

$[\ldots]$

CHRISTOPHER. You said 'uppity nigga'. You did. Deny.

BRUCE. Only because you did. My God! It was a quote!

CHRISTOPHER. Yeah, but you shouldn'ta said it.

BRUCE. Oh, so only you can say it?

CHRISTOPHER. It's not polite.

BRUCE. I know it isn't and, um ...

I'm sorry, excuse me ...

I feel sick ... (3. 76-77) 
CHRISTOPHER. I don't believe you. You call me nigga. You say it's voodoo.

BRUCE. It was a joke!

CHRISTOPHER. Oh funny joke. Do you see me laughing? I've got one for you. I'm gonna Lay Charges. 'Cos I ain't staying here, man. You'll never keep me locked up, white man. This is one nigga you don't get to keep white man. 'Cos I'm gonna bark every time you come near. D'you understand? (3.103)

Christopher attempts to fight back against the oppression of institutions and society as well. He reminds Bruce of his insulting racial expressions "nigga" and "voodoo" which he mentions at the beginning of the play. Christopher manages to use the same discriminatory words and epithets to resist the doctors' prejudice, and even threaten them. Christopher's powerful language avenges the oppression to which he is subjected. He does not address Bruce as a white doctor, but as a white oppressor who wants to lock him up and control him.

In Blue/Orange, Joe Penhall attempts to question and challenge some of the socially constructed concepts and perceptions by addressing issues of disability, racism (especially institutional racism), oppression, the ideology of supremacy, and psychiatry hospitalization. Blue/Orange does not only reveal institutional racism and power struggle between patients and doctors, but also between clinical staff as well. By displaying the degenerative effects of racism on the mental condition of Black people, Blue/Orange calls for the audience's attention towards the practices of racism in institutions and society. By testing the long-established ideas about psychological disability, white psychiatry, and institutional racism, Joe Penhall endeavors to unmask the role of society and institution in discriminating and marginalizing black people with disabilities. 
To conclude, through the exploration of the intersectionality of disability and racism, this study has attempted to present the lived experiences of black disabled people in society. Blue/Orange dramatically expresses the experiences, feelings, and expectations of a Black man with psychological disability in a White milieu in a way that invokes people's consideration of disability and racism. 


\section{Works Cited}

Ansley, Frances Lee. "Stirring the Ashes: Race Class and the Future of Civil Rights Scholarship". Cornell Law Review, vol. 74, no. 6, 1989, pp. 9931077.

Baynton, Douglas. "Disability and the Justification of Inequality in American History". The New Disability History: American Perspectives, edited by Paul Longman and Lauri Umansky, New York University Press, 2001, pp. 33- 57.

Beauchamp, Milies, et al. Disabled Literature: A critical Examination of the Portrayal of Individuals with Disabilities in Selected Works of Modern and Contemporary American Literature. Brown Walker Press, 2015.

Bell, Derrick. "Brown V. Board of Education and the Interest Convergence Dilemma". Critical Race Theory: The Key Writings that Formed the Movement, edited by Kimberle Crenshaw \& et al., The New Press, 1995, pp. 20-29.

Beveridge, Allan. "R. D. Laing Revisited". History of Psychiatry, vol. 22, 1998, pp. 452-456.

Bill, Hooks. Yearning: Race, Gender, and Cultural Politics. Routledge, 2015.

Bobo, Lawrence, and Cybelle Fox. "Race, Racism, and Discrimination: Bridging Problems, Methods, and Theory in Social Psychological Research”. Social Psychology Quarterly, vol. 66, 2003, pp. 319- 332.

Bracey, Glenn E. "Toward a Critical Race Theory of State". Critical Sociology, vol. 41, 2015, pp. 553- 572. 
Chun-Yi, Shih. “"The Worst Pariah": Schizophrenia and Racism in Joe Penhall's Blue/Orange". Sun Yat-sen Journal of Humanities, no. 45, 2018, pp. 77-95.

Clarke, Simon. Social Theory, Psychoanalysis and Racism. Palgrave, 2003.

Clements, Rachel, editor. Joe Penhall: Blue/Orange. Bloomsbury, 2013.

Davis, Lennard. Enforcing Normalcy: Disability, Deafness, and the Body. Verso, 1995.

Diagnostic and Statistical Manual of Mental Disorders: DSM-5, 5th ed. Arlington, VA: American Psychiatric Association, 2013.

Erevelles, Nirmala, and Andrea Minear. "Unspeakable Offences: Untangling Race and Disability in Discourses of Intersectionality". The Disability Studies Reader, $4^{\text {th }}$ edition, edited by Lennard Davis, Routledge, 2013.

Fawcett, Barbara, and Fran Waugh, editors. Addressing Violence, Abuse, and Oppression: Debates and Challenges. Routledge, 2008.

Fernando, Suman. Cultural Diversity, Mental Health and Psychiatry: The Struggle against Racism. Routledge, 2003.

Guyot, Arnold. Physical Geography. New York, 1978.

Garland-Thomson, Rosemarie. Staring: How We Look. Oxford University Press, 2009.

Hartlep, Nicholas. "Critical Race Theory: An Examination of its Past, Present, and Future Implications". ERIC (ED506735), 2009.

"Joe penhall". Peoplepill, https://peoplepill.com/people/joe-penhall/. Accessed 20 April 2019. 
Krogman, W. M. "What We Do Not Know About Race". Scientific Monthly, vol.57, 1943, pp. 104-198.

Lopez, Ian Haney. "The Social Construction of Race: Some Observations on Illusion, Fabrication, and Choice". Harvard Civil Rights Law Review, vol. 29, 1994, pp. 1-62.

Martinez, Aja Y. "Critical Race Theory: Its Origins, History, and Importance to the Discourses and Rhetorics of Race". Frame, Journal of Literary Studies, vol. 27, no. 2, 2014, pp. 9-27.

Penhall, Joe. Blue/Orange. Methuen Drama, 2001.

Schalk, Sami. Bodyminds Reimagined. Duke University Press, 2018.

Schizophrenia: The Nice Guideline on Core Intervention in the Treatment and Management of Schizophrenia in Adults in Primary and Secondary Care. The British Psychological Society and the Royal College of Psychiatrists, 2010.

Siebers, Tobin. Disability Theory. University of Michigan, 2008.

Sierz, Aleks. Rewriting Nation: British Theatre Today. Methuen Drama, 2013.

Smedley, Audrey, and Brian D. Smedley. "Race as Biology Is Fiction, Racism as a Social Problem Is Real: Anthropological and Historical Perspective on the Social Construction of Race". American Psychologist, vol. 60, no. 1, 2005, pp. 16-26.

Tate, William F. "Critical Race Theory and Education: History, Theory, and Implications". Review of Research in Education, vol. 22, 1997, pp. 195- 247.

Weir, Antony John. Theatre as Public Discourse: A Dialogic Project. 2016. University of Exeter, $\mathrm{PhD}$ dissertation. 
"What is Psychiatric Disability and Mental Illness?" Center for Psychiatric Rehabilitation, https://cpr.bu.edu/resources/reasonableaccommodations/what-is-psychiatric-disability-and-mental-illness/. Accessed 28 Oct. 2019.

Ziaka, Katerina. "In/Sanity as a Means of Repoliticization for British "New Political Writing". Journal of Theory and Criticism, vol. 24, 2017, pp. 134144. 